\title{
Plant Bioestimulants: Compost Tea and Bioslurry Characterization
}

\author{
M. Iván Funes-Pinter ( $\square$ ifunespinter@fca.uncu.edu.ar) \\ CONICET Mendoza https://orcid.org/0000-0002-4137-0425 \\ Gabriel Pisi \\ Instituto Nacional de Tecnologia Agropecuaria \\ Matías Aroca \\ Instituto Nacional de Tecnologia Agropecuaria \\ Laura Elizabeth Martínez \\ Instituto Nacional de Tecnologia Agropecuaria \\ Marcela Fernández \\ Instituto Nacional de Tecnologia Industrial \\ Ernesto Martín Uliarte \\ Instituto Nacional de Tecnologia Agropecuaria
}

\section{Research}

Keywords: Petunia hibrida, Impatiens walleriana, nutrients, toxicology, compost extract, bioproducts

Posted Date: August 13th, 2020

DOI: https://doi.org/10.21203/rs.3.rs-56311/v1

License: (c) (1) This work is licensed under a Creative Commons Attribution 4.0 International License. Read Full License 


\section{Abstract}

In the present study, the quality of aerated and non-aerated compost teas and bioslurry as bio-fertilizers and its application on two plant species in different substrates were tested. Compost tea brewed from a mixture residues compost presented higher nutrient content than that brewed from grape marc composted. Aeration, with shorter extraction time, resulted in higher $\mathrm{pH}$, but in general with lower nutrient concentration, while bioslurry, presented higher nitrogen content. No pathogen and toxic effects were detected in the bio-products. Finally, Bio-products were evaluated in ornamental plant species: Petunia hibrida and Impatiens walleriana, where compost teas and bioslurry presented highly variable properties and effects on plant growth, depending on the substrate and species used. While in sand no significant effect on plant biomass and pigments were observed, in compost and commercial substrate bioslurry presented values similar to the traditional fertilizer. Compost tea presented variable results with no differences between aerated and non-aerated, both increasing carotenoids in I. walleriana in sand. We conclude that aeration showed no differences in compost tea quality, whilst bioslurry demonstrated to increase plant biomass at similar values to traditional fertilizer. Our results demonstrated that alternative products are an efficient, safe, ecological, and economical alternative to traditional products.

\section{Highlights}

- Non-aerated and longer brewing time enhances nutrient extraction.

- Compost achieved from diverse residues results in a nutrient richer byproducts.

- Bioslurry increased plant biomass at values similar to commercial fertilizer.

- The Bio-products effect was highly dependent on plant species and substrate used.

\section{Introduction}

In the last decades, population growth with the consequent food demand had determined an excessive use of synthetic agrochemicals. While these products may increase short-time crop production, they cause diverse environmental problems, mainly due to their high toxicity and mobility and low biodegradability [1, 2]. Heavy use of fertilizer has led to environmental damages including soil and water pollution, also delivering gases that contribute to the greenhouse effect [3]. This situation has led to the necessity to consider more sustainable ways of production that provide highquality aliments reducing environmental impacts.

It is necessary, therefore, to develop and implement the use of alternative products that minimize agricultural impacts. Bio-products are by-products from biological sources, that provide nutrients, and beneficial microorganisms that promote plant growth. Usually, bio-products are derived from organic wastes that exploit the presence of nutrients and benefic microorganisms, while the residues are treated and reduced. Composting is an alternative that allows to relatively safe treat a high quantity of organic waste, while a high-value product is generated [4, 5]. It is an aerobic biological process by which biodegradable organic materials are transformed into a homogeneous product assimilable by plants [6, 7, 8].

The filtered suspensions of compost in water, denominated compost teas, are able to extract soluble nutrients and benefic microorganisms to be used as plants fertilizer or as biopesticide $[9,10]$. It may be obtained from two main processes: aerated and non-aerated. The first one is usually associated to reduced elaboration time, but it is necessary the use of aerators and energy sources available, while in non-aerated, no energy and equipment are needed, but the time required may be extended. Despite non-aerated compost tea is usually indicated as phytotoxic and to benefits pathogen growth, no reliable supporting information has been found [11]. Otherwise, Shrestha et al. [12] reported that aeration may favor metabolites extraction, and the consequent higher pathogen control and plant nutrition quality. However, some author reports no differences of compost teas properties, and this differentiation has been mainly associated to the material source and not to brewing method [13,14].

Another promising liquid bio-product is the bioslurry, which, unlike compost tea, is produced from fresh material with no previous treatment, like composting, and it is mostly an anaerobic process. In general, studies referred to this bioproduct, have demonstrated the exploitation of the liquid part of the biodigestate, being a residue from biogas production, as fertilizer, plague controller, and even in bioremediation [15, 16, 17, 18]. In this sense, The Food and Agriculture Organization (FAO) [19] has developed a protocol for bioslurry elaboration from fresh material (e.g. vegetal remains, animal manure, ashes, and bone meals), specifically designed to plant nutrition and growth promotion, and dismissing biogas production. Besides the low cost and the high potential of this product, no studies evaluating its properties were found, while mostly, are focalized on the methanogenic process effluent $[20,21]$.

In general, biofertilizers, both solid and liquid, are able to provide microorganisms, long and short term macro and micronutrients at levels even superior to traditional products. Several authors have reported radical and aerial biomass and germination increase in ornamental plants and crops, by the addition of compost tea and bioslurry originated from animal and vegetal rests $[\mathbf{1 0}, \mathbf{2 2}, \mathbf{2 3}, \mathbf{2 4}$. While many bacterial, fungal and archaeal genders have been identified by metagenomics and culture isolation, it is not well known the microbial communities and the mechanisms implicated in the positive effects on crops $[25,26]$. However, it is necessary to consider that these product properties are highly dependent on the material raw, elaboration process, and conservation conditions, due to transformation process is carried out by the microorganisms present in the raw material and or by inoculation, and the effect of all these variables remain mostly unknown $[27,28]$. 
In Argentina, ornamental plant growing in pots under greenhouse conditions is an important agricultural activity, centered mainly in Buenos Aires, Corrientes, Santa Fe, and Formosa, while Mendoza is the main producer in the central-west regions [29]. However, one of the main inconvenience for producer is the expensive cost of substrates and fertilizers and the high dependence on these products. As an example, one of the most utilized substrates is Sphagnum moss peat, which characteristics allow adequate germination and seedling growth, nonetheless, due to the excessive cost and unsustainable production, its use has started to be limiting [30, 31, 32, 33]. This situation motivates the searching and developments of high quality and low-cost alternative products, ideally brewed from materials attainable by local producers [34, 35].

The main aim of this study was to evaluate compost tea and bioslurry potentiality to be used as fertilizers in ornamental plants. As specific objectives, we pretend to (1) characterize and determine the differences among the liquid product attributes related to different raw materials; (2) the effect of aeration in compost tea quality; and (3) test the liquid products in different substrates in ornamental plants. Our initial hypotheses were that (1) compost tea produced from a mixed residues compost and aeration, would derivate in a higher nutrient and microorganisms content in the final product; (2) the composting of the raw material would increase product quality compared with fresh material, due pathogen inhibition, and organic matter decomposition and higher nutrient solubility.

\section{Methods}

\subsection{Compost tea and bioslurry brewing}

The previous composting process was carried out in $4 \mathrm{~m}^{3}$ turned windrows. Two different composts were made: from exhausted grape marc (GC) and from a mixture (MC) of exhausted grape marc, goat manure, leaves from garden raking and alfalfa in a volume proportion 1:1:3:0.5, obtaining an initial $\mathrm{C} / \mathrm{N}$ ratio around $20-25$ in both cases, according to [36].

The compost teas were prepared according to Marín et al. [13], eluting a 1:3 (v:v) compost:water proportion, in 2.5 L PET flask. In non-aerated compost tea elaboration, both kinds of compost were suspended in free chlorine water, extracted from a subterranean well, at the proportion indicated and stored at $20^{\circ} \mathrm{C}$ during 10 days in darkness with a periodic homogenization. Aerated compost tea brewing was similar, but the process lasts for $48 \mathrm{~h}$, and fishbowl aerators were added to maintain oxygen saturation in the suspension. In all cases, to obtain the final product, the suspensions were filtered and stored in darkness at $15-20^{\circ} \mathrm{C}$. A total of four compost teas were produced: non-aerated grape marc compost tea (NAG), aerated grape marc compost tea (AG), non-aerated mixture residues compost tea (NAM) and aerated mixture compost tea (AM), the free chloride water was used as control $\left(\mathrm{H}_{2} \mathbf{O}\right)$.

Bioslurry (B), also known as liquid enriched biofertilizer, was brewed according to FAO protocol [19], for agricultural bioproducts. The anaerobic process was carried in a $200 \mathrm{~L}$ PET recipient, provided with a screw cap and gas trap. The ingredients were: $10 \mathrm{~kg}$ of fresh vegetal material, $60 \mathrm{~L}$ of fresh goat manure, $3 \mathrm{~kg}$ of wood ashes, $4 \mathrm{~kg}$ of bentonite, $500 \mathrm{~g}$ of chicken eggshells, $3 \mathrm{~kg}$ of bone ashes, $5 \mathrm{~L}$ of cow milk, and free chloride water to a final volume of $170 \mathrm{~L}$. After 2 months resting, the product was filtered and stored in darkness at $15-20{ }^{\circ} \mathrm{C}$. Final bioslurry was diluted at $10 \%$ with free chloride water.

\subsection{Bioproducts characterization}

\subsubsection{Physicochemical parameters}

Electrical conductivity (EC) and pH were determined directly in paper filtered samples of each product. In dried $50 \mathrm{~mL}$ samples, total nitrogen (TN) was determined by Kjeldahl and steam trawl distillation method [37], and ammonium nitrogen $\left(\mathbf{N}-\mathbf{N H}_{\mathbf{4}}\right)$ and nitric nitrogen $\left(\mathbf{N}-\mathrm{NO}_{3}\right)$ by $\mathrm{KCl}$ extraction [38].

Total elements determinations were assessed by $\mathrm{HCl}$ digestion in $550{ }^{\circ} \mathrm{C}$ calcined samples. $\mathbf{P}$ was extracted with molibdic methavanadate solution and measured at $420 \mathrm{~nm}$ of absorbance (UV-VIS Milton Roy Spectrophotometer), in base to TMECC [39], while K, Ca, Mg, Fe, Cu, Zn, and Mg concentration were measured by atomic absorption spectrophotometry (Perkin Elmer Analyst 200).

\subsubsection{Microbiological parameters}

To microbiologically characterize the bioproducts, total aerobic viable fungus (TAVF), bacteria (TAVB), and N fixing microorganisms were determined by the pour plate method in $9 \mathrm{~cm}$ Petri dishes, at dilutions $10^{-1}, 10^{-2}$, and $10^{-3}$ with sterile distilled water. Glucose potato agar with streptomycin ( 7.5 ppm), nutritive agar and LG medium for Azotobacter and Azomonas spp. were used respectively. Colony-forming units were counted in each plate after $48 \mathrm{~h}$ for TAVF and TAVB, and 7 days for nitrogen-fixing microorganisms at $28{ }^{\circ} \mathrm{C}$ of incubation $[\mathbf{4 0}, \mathbf{4 1}]$.

Nitrifying and ammonifying microorganisms were quantified using McGrady most probable number (MPN) method [41]. Ammonifying microorganisms were grown in asparagine rich media for 7 days, and orange complex formation was considered positive, after Nessler reactive 
addition. Nitrifying bacteria was determined in ammonium sulfate rich media during 21 days, where blue coloration was considered as positive after addition of sulfuric diphenylamine To ensure bioproducts safety, pathogens content was determined: Total coliforms (TC) counting was performed in VRB lactose medium a, according to ISO 4832:2016 normative; Escherichia coli in TBX medium, based on ISO 16649-2:2001(revision 2012); and Salmonella sp. was determined by BAM online-FDA. Also, plant growth promotion bacteria (PGPB) presence was analyzed, including Pseudomonas aeruginosa and Bacillus cereus, by BAM-FDA method. The analyses were performed in the Laboratorio de Microbiología of Instituto Nacional de Tecnología Industrial (INTI-Mendoza).

\subsubsection{Toxicology test}

To perform this assay, Lactuca sativa var Grandrapids seeds were superficially sterilized and exposed to the bio-products samples based on the US EPA [42] procedure. Considering the results of physicochemical analyses, mixed compost teas were considered as compost and bioslurry as fresh biomass byproducts. In $90 \mathrm{~mm}$ Petri dishes, 20 seed were placed on filter paper and exposed to 0, 25, 50, and 100\% purity of the bio-products. A commercial fertilizer (F, 200 ppm solution Hakaphos® Rojo, NPK 18-18-18, Compo expert, Spain) was considered as a traditional treatment. Serial dilutions were performed with well water $\left(\mathrm{H}_{2} \mathrm{O}\right)$, also used in product brewing. Germination power and seed viability were tested using distilled and autoclaved water $\left(\mathrm{H}_{2} \mathrm{O}_{\mathrm{d}}\right)$. All the determination was done by triplicate, at $20^{\circ} \mathrm{C}$ in obscurity, for 5 days. To evaluate the toxic effect, total germination, and hypocotyl and root elongation were analyzed.

\subsection{Pot assay}

\subsubsection{Experimental design}

To evaluate the bio-products performance in plants, pot assay with flowering plants growing in different substrates was settled. In base to their previous properties, only two of the compost teas were selected to be tested as fertilizer in this assay. A total of 36 treatments, distributed in 6 complete randomized blocks were performed, with 3 factors: ornamental plants, with two levels: Petunia hibrida (Ph) and Impatiens walleriana (Iw); fertilizers with six levels: non-aerated mixture residues compost tea (NAM), aerated mixture compost tea (AM), a 1:1 (v:v) MA and NAM combination (A-NAM), bioslurry (B), commercial fertilizer (F, 200 ppm), and water as control $\left(\mathbf{H}_{2} \mathbf{O}\right)$; and substrate, with three levels: Sand, Commercial substrate $(Z$ floricultura, Terrafertil, línea profesional, Argentina), and Compost (MC). The compost used in this assay was the mixture compost, by which NAM and AM was brewed, considered as the rich in nutrients and biological activity substrate. Sand was used as a poor substrate, in order to enhance products effects; while commercial as the traditional substrate used by nursery plant production.

Plants of $3 \mathrm{~cm}$ were selected and transplanted to $1 \mathrm{~L}$ pot with the substrates indicated. The experiment was performed during two months, under greenhouse condition, at environmental temperature and humidity. All products were applied at $50 \mathrm{~mL}$ every $48 \mathrm{~h}$ as irrigation, supplemented with well water if necessary to maintain substrate moisture at field capacity.

\subsubsection{Plant parameters}

Aerial and root fresh and dry biomass (FWa, DWa, FWr, and DWr, respectively), and sapling number per plant were determined in 60 days old plants. As estimation of plant nutrition, photosynthetic pigments content were determined. According to [43], chlorophyll (TChl, as the summary of chlorophyll A and B) and carotenoids (Carot) were measured by extraction with $5 \mathrm{~mL}$ dimethyl sulfoxide (DMSO) of four $0.2 \mathrm{~cm}{ }^{2}$ (20-30 mg) leaves discs of the 7th leaf. After $45 \mathrm{~min}$ in water bath incubation, samples were centrifuged at $10000 \mathrm{G}$ during $10 \mathrm{~min}$, and ChIA, ChIB, and Carot, were estimated measuring extracts absorbance at 665, 649 and $480 \mathrm{~nm}$, respectively (Cary-50 UV-vis spectrophotometer, Varian Inc., Palo Alto, CA, USA). Finally, chlorophyll relative content, expressed as SPAD index was determined in the 7th leaf, using a portable chlorophyll meter (SPAD-502, Konica Minolta Sensing, Osaka, Japan).

\subsection{Statistical analyses}

According to assumptions compliment (tested by Shapiro-Wilk normality and residues regression tests), ANOVA and non-parametric analyses were performed. Aeration and raw material effect on compost teas quality were evaluated by factorial ANOVA tests, while in pot assay, Kruskal-Wallis with pair comparison and ANOVA LSD Fisher tests was achieved considering $p<0.05$, using InfoStat 2015 software (Grupo InfoStat, Universidad Nacional de Córdoba, Argentina, http://www.infostat.com.ar). All results are expressed as medium value \pm standard deviation.

\section{Results}

\subsection{Physico-chemical characterization}

Page $4 / 16$ 
As it is shown in Table 1, the highest $\mathbf{p H}$ value was in $\mathbf{B}(8.42 \pm 0.07$, medium value \pm standard deviation), and no significant differences were found respect to $\mathrm{H}_{2}$ O. Non-aerated compost teas presented the lowest significantly pH values (6.98 \pm 0.02 and $7.32 \pm 0.03$, respectively for NAG and NAM). Aeration and raw material presented a significant effect on $\mathrm{pH}$ of compost teas, with lower values in NA and $\mathbf{G}$ products. On the contrary, EC was the lowest in $\mathbf{B}$ and $\mathbf{H}_{2} \mathbf{O}(1.65 \pm 0.01$ and $1.05 \pm 0.06)$ and no significant differences were found among teas. Aeration and raw material presented no significant effect on EC, suggesting no differences in total ion extraction of the different compost tea brewing process.

In general, nutrients content was variable among the products. $\mathbf{N}^{-N_{3}}{ }_{3}^{-}$and $\mathbf{N}^{-N_{4}}{ }^{+}$were significantly higher in $\mathbf{B}\left(7.86 \pm 1.06\right.$ and $40.77 \pm 3.41$ mg L $\left.{ }^{-1}\right)$ compared with AG, NAG and $\mathrm{H}_{2} \mathrm{O}$ (2.76 \pm 0.16 and $17.60 \pm 3.45,3.56 \pm 0.03$ and $3.00 \pm 2.04,1.05 \pm 0.06$ and $2.21 \pm 0.43$, respectively), with no difference with $\mathbf{A M}$ and NAM. P was significantly higher in all teas $\left(30.12 \pm 0.47,27.45 \pm 3.32,24.69 \pm 1.95\right.$ and $19.02 \pm 0.23 \mathrm{mg} \mathrm{L}^{-1}$, respectively for NAM, AM, NAG and $\mathbf{A G})$, respect to $B$ and $\mathrm{H}_{2} \mathrm{O}\left(2.95 \pm 0.01\right.$ and $\left.0.20 \pm 0.01 \mathrm{mg} \mathrm{L}^{-1}\right)$. All products presented significantly higher $\mathrm{K}$ concentration than $\mathrm{H}_{2} \mathrm{O}(3.20$ $\left.\pm 1.10 \mathrm{mg} \mathrm{L}^{-1}\right)$, being AM and NAM (637.00 \pm 9.96 and $635.50 \pm 3.37 \mathrm{mg} \mathrm{L}^{-1}$, respectively) the products with the highest content. Mixture raw material contributed significantly higher $\mathbf{P}$ and $\mathbf{K}$ to the compost tea, while aeration and shorter extraction time benefits $\mathrm{K}$ and prejudice $\mathrm{P}$ extraction.

Aeration (and shorter extraction time) significantly reduced $\mathrm{Ca}, \mathrm{Mg}$, and Fe extraction in compost teas, while compost teas brewed from the composted mixture of residues, presented significantly higher $\mathrm{Mg}, \mathrm{Na}$, Fe, and $\mathrm{Zn}$ content. All compost teas presented higher nutrient content than $\mathrm{H}_{2} \mathrm{O}$, while $\mathrm{B}$ was no significantly different, suggesting a high extraction in the elaboration process. Ca content was significantly higher in all teas $\left(238.17 \pm 46.84,204.57 \pm 15.20,149.70 \pm 36.56,145.97 \pm 5.19 \mathrm{mg} \mathrm{L}^{-1}\right.$, respectively for $\mathbf{N A M}, \mathbf{N A G}, \mathbf{A M}$, and $\left.\mathbf{A G}\right)$ than $\mathrm{H}_{2} \mathbf{O}$ and $\mathbf{B} ; \mathbf{M g}, \mathbf{N a}$, and Fe were significantly higher in $\mathbf{A M}$ and NAM; and there were no differences among bioproducts in $\mathbf{C u}$ and $\mathbf{Z n}$ content, all with higher values than $\mathrm{H}_{2} \mathbf{O}$, being significant in Zn. Finally, Mn was significantly higher in NAM, AG, and AM (0.16 $\pm 0.00,0.13 \pm 0.02,0.04 \pm 0.00 \mathrm{mg} \mathrm{L}^{-1}$, respectively), respect $\mathbf{H}_{2} \mathbf{O}$ and $\mathbf{B}$. Due to the higher nutrient values of $\mathbf{M}$ compost teas, they were the compost teas selected for further analyses.

\subsection{Microbiological characterization}

According to non-parametric tests, all products presented higher microorganism content than $\mathrm{H}_{2} \mathrm{O}$, suggesting nutrient and benefic condition to its growth (Table 3). No effect of aeration and raw material was observed among compost teas. TVAB presented no difference among bioproducts, where NAG (4.47 $\left.\pm 0.28 \mathrm{Log} \mathrm{CFU} \mathrm{mL}^{-1}\right)$ was the product with the higher value. Non-aerated compost teas presented the highest TVAF content (1.00 \pm 0.48 and $0.78 \pm 0.42$ Log CFU mL ${ }^{-1}$, for NAM and NAG, respectively), with no differences with AG $\left(0.51 \pm 0.29\right.$ Log CFU mL $\left.^{-1}\right)$, while B, AM, and AG was not significantly different from $\mathrm{H}_{2} \mathrm{O}$ (no detected). NAM and $\mathbf{A M}$ were the products with higher nitrifying microorganism content (1.23 \pm 0.52 and

$0.96 \pm 0.58 \mathrm{Log} C F U \mathrm{~mL}^{-1}$ ), being significantly higher than $\mathrm{H}_{2} \mathrm{O}$ (no detected). No differences were detected among the products and water in $\mathbf{N}_{2}$ fixing and ammonifying content.

Non-parametric analysis indicates that total coliforms content was highly variable, with the highest value in $\mathrm{AM}\left(3.44 \pm 0.79 \mathrm{Log}_{10} \mathrm{CFU} \mathrm{mL}^{-1}\right)$, significantly different to B and $\mathrm{H}_{2} \mathrm{O}\left(0.97 \pm 0.85\right.$ and $1.40 \pm 0.78 \mathrm{Log}_{10} \mathrm{CFU} \mathrm{mL}{ }^{-1}$, respectively), both with the lowest values. Salmonella sp. and $E$. coli were no detected in the bio-products, suggesting a correct elaboration and sanitization in all cases.

PGPR, represented by $\boldsymbol{P}$. aeruginosa and $\boldsymbol{B}$. cereus, showed no significant differences and high variability among products (Table 4). These results suggest that the well water used to brew them, was the main source of these microorganisms, with no effect in their growth of the raw material and the nutrient content in the bio-products elaboration.

\subsection{Bio-products toxicology test}

The toxicology test, made on L. sativa seeds, presented no significant differences in germination among the factors evaluated. Both factors, Products, and Dilution, did not significantly affect germination, however only the combination $\mathbf{B}_{\mathbf{5 0} \%}$, $\mathbf{A M}_{\mathbf{2 5} \%}$, and $\mathbf{A} \mathbf{M}_{\mathbf{5 0} \%}$ were significantly higher than $\mathrm{B}_{100 \%}$, and $\mathrm{NAM}_{100 \%}$, with no differences with $\mathrm{H}_{2} \mathrm{O}$ and $\mathrm{H}_{2} \mathrm{O}_{d}$ (Figure $1 \mathrm{~A}$ ), suggesting no phytotoxicity.

In both, root and hypocotyl elongation, the dilution produced no effect; however, there were differences among product, all with significantly superior values than $\mathrm{H}_{2} \mathbf{O}_{d}$. In hypocotyl length, $\mathrm{F}$ was the product with the lowest value and did not differentiate from $\mathrm{H}_{2} \mathbf{O}$, while $\mathbf{B}$, AM, and $\mathbf{N A M}$ presented the highest elongation (Figure 1B). Similar results were found in root elongation, all products above $\mathbf{H}_{2} \mathbf{O}_{d}$, but in this case, $\mathbf{F}$ did not differentiate from B, both with significantly lower values than $\mathrm{H}_{2} \mathrm{O}, \mathrm{NAM}$, and $\mathrm{AM}$ (Figure $1 \mathrm{C}$ ). No toxic effects were found in the product tested, on the contrary, the products, mainly compost teas, stimulated plant elongation.

\subsection{Impatiens walleriana biomass}

Page 5/16 
All biomass values were highly affected by substrate, being the lowest values achieved in sand and the highest in compost treatments. In Sand, no differences in plant biomass were detected among products. In Commercial substrates, the teas seemed to reduce both aerial and root dry biomass, while $\mathbf{B}$ and $\mathbf{F}\left(1.27 \pm 0.25\right.$ and $1.09 \pm 0.18 \mathrm{~g}$, respectively) increased but not at a significant level, compared to $\mathrm{H}_{2} \mathbf{O}(0.60 \pm 0.24 \mathrm{~g})$. A significant effect of $\mathbf{B}(1.75 \pm 0.42 \mathrm{~g})$ on aerial weight was observed in Compost treatments, no differences were detected among the rest products of products respect to $\mathrm{H}_{2} \mathrm{O}(1.33 \pm 0.18 \mathrm{~g}$ ), where compost teas presented the lowest aerial and root biomass values.

\subsection{Petunia hibrida biomass}

Among substrates, compost presented a significant effect, increasing plant growth, while sand and commercial substrate did not differentiate between them. In sand, only $\mathbf{F}(0.99 \pm 0.15 \mathrm{~g})$ ) presented a significant effect on dry aerial biomass, while, in general, no differences among treatments were detected. In Commercial substrate, $\mathbf{B}$ and $\mathbf{F}(1.35 \pm 0.44$ and $1.21 \pm 0.13 \mathrm{~g})$ in aerial, and only $\mathbf{B}(0.21 \pm 0.04 \mathrm{~g})$ in root biomass, were increased respect to $\mathrm{H}_{2} \mathrm{O}(0.42 \pm 0.11$ and $0.13 \pm 0.04 \mathrm{~g}$, respectively for aerial and root dry weight). In compost, $\mathbf{F}$ and $\mathbf{B}(1.93 \pm 0.11$ and $1.86 \pm 0.28 \mathrm{~g})$ significantly increased aerial, while A-NAM $(0.29 \pm 0.04 \mathrm{~g})$ decreased root biomass respect to $\mathrm{H}_{2} \mathrm{O}(1.54 \pm 0.28$ and $0.36 \pm 0.09 \mathrm{~g}$, respectively for aerial and root dry biomass, Figure 2A), and no differences were detected among the rest of products.

\subsection{Sapling number}

In both species, Compost was the substrate that produced significantly higher sapling number per plant. In I. walleriana, no differences were detected among products in sand and compost treatments, while in Commercial, AM and A-NAM (10 \pm 3.22 and $3.67 \pm 1.51$ sapling per plant), significantly reduced sapling number per plant, respect to $\mathrm{H}_{2} \mathrm{O}(12.5 \pm 4.46)$. However, in $\boldsymbol{P}$. hibrida, B and $\mathbf{F}$ significantly increased this parameter in Compost $(6.17$ \pm 1.47 and $6.5 \pm 0.84$ ) and Commercial ( $4.17 \pm 0.75$ and $3.67 \pm 1.75$, respectively), while only $\mathbf{F}(2.83 \pm 0.98)$ in Sand.

\subsection{Pigments content}

In general, all products increased pigments content, but only B and $\mathbf{F}$ presented significantly higher values, except in compost treatments. The substrate produced a significant effect on pigments content, with the highest values in compost, followed by sand, and commercial substrate with the lowest ones.

Among compost treatments, no differences were detected (Table 5), except in TChl content of $P$. hibrida, in which $\mathbf{B}$ and $\mathbf{F}$ (91.78 \pm 23.35 and 86.30 $\pm 34.01 \mu \mathrm{g} \mathrm{mg}^{-1}$, respectively) presented significantly higher values than $\mathrm{H}_{2} \mathrm{O}\left(60.11 \pm 17.43 \mu \mathrm{g} \mathrm{mg}^{-1}\right)$. Under sand conditions, carotenoids were significantly increased by B and A-NAM $\left(17.66 \pm 2.93\right.$ and $\left.16.16 \pm 2.08 \mu \mathrm{g} \mathrm{mg}^{-1}\right)$ in $\boldsymbol{I}$. walleriana, and NAM $\left(17.31 \pm 1.96 \mu \mathrm{g} \mathrm{mg}{ }^{-1}\right)$ in $P$. hibrida, compared with respective controls (10.70 \pm 3.35 and $\left.12.86 \pm 2.84 \mu \mathrm{g} \mathrm{mg}^{-1}\right)$. TChl concentration was no different among products in $\mathbf{l}$. walleriana, being $\mathbf{B}$ the treatment with the highest value, while $\mathbf{F}\left(70.32 \pm 11.18 \mu \mathrm{g} \mathrm{mg}^{-1}\right)$ was significantly higher than $\mathrm{H}_{2} \mathrm{O}\left(31.79 \pm 3.70 \mu \mathrm{g} \mathrm{mg}{ }^{-1}\right)$ with no differences with B $\left(52.14 \pm 8.21 \mu \mathrm{g} \mathrm{mg}^{-1}\right)$ in P. hibrida.

In commercial substrate, there were no differences among products for carotenoids concentration of $\boldsymbol{I}$. walleriana leaves, while in $\boldsymbol{P}$. hibrida, $\mathrm{F}$ and $\mathbf{A}$ NAM $\left(15.36 \pm 2.78\right.$ and $\left.14.16 \pm 0.83 \mu \mathrm{g} \mathrm{mg}^{-1}\right)$ significantly increased it respect to $\mathrm{H}_{2} \mathrm{O}\left(10.28 \pm 1.00 \mu \mathrm{g} \mathrm{mg}{ }^{-1}\right)$. Finally, TChl were significantly higher in $\mathbf{F}$ and $\mathbf{B}\left(80.66 \pm 17.98\right.$ and $\left.66.02 \pm 11.93 \mu \mathrm{g} \mathrm{mg}^{-1}\right)$ in $\boldsymbol{P}$. hibrida, and no differences were detected for $\boldsymbol{I}$. walleriana, with the highest value in $\mathbf{B}$ (11.82 $\left.\pm 1.75 \mu \mathrm{g} \mathrm{mg}{ }^{-1}\right)$.

\subsection{SPAD index}

No significant differences were detected among substrates in SPAD values. In sand, all products increased this parameter in I. walleriana, respect to $\mathrm{H}_{2} \mathbf{O}$, while only $\mathbf{F}(33.15 \pm 2.48)$ presented significantly higher values in $\boldsymbol{P}$. hibrida. In commercial, only $\mathbf{B}$ and $\mathbf{F}(35.62 \pm 4.14$ and $35.33 \pm 4.24)$, presented significantly higher values in $\boldsymbol{I}$. walleriana, though all product increased it in $\boldsymbol{P}$. hibrida, being $\mathbf{F}$ and $\mathbf{B}(38.26 \pm 2.35$ and $37.25 \pm 2.45)$ the highest. In compost, the products did not produce significant effect on SPAD values in I. walleriana, but in P. hibrida, B and F (37.84 \pm 2.79 and 37.63 $\pm 1.65)$ were significantly higher than $\mathrm{H}_{2} \mathrm{O}(31.53 \pm 3.94)$.

\section{Discussion}

In this study, quality of compost teas and bioslurry and its application on two plant species in different substrates were tested. Results suggested that aeration, with shorter brewing time, and the presence of manure results in a higher $\mathrm{pH}$ compost tea, besides the high $\mathrm{pH}$ of well water, by which the products were brewed, typical of the region (around 8.34) and its buffer effect that may reduce the pH variation by acid formations. In this sense, 
$\mathrm{pH}$ of exhausted marc compost presented $\mathrm{pH}$ around 6.50, while mixture compost was 7.80 [36], explaining the main difference among derived products. Moreover, exhausted grape marc compost by-products may result in lower $\mathrm{pH}$ due the higher $\mathrm{C}$ content of compost and a higher $\mathrm{CO}_{2}$ formation from microbial activity and dissolution [44]. No differences were detected in aeration of compost tea in EC, however NAM and AM presented higher values suggesting a higher soluble nutrients in mixture compost. Beside the low value in B it is important to consider the dilution made. The excessive high EC value of the pure product may be explained by the high time of retention in elaboration process, with a higher probability of mineralization of the fresh material and its dissolution, which obligates to use it at $10 \%$.

Nitrogen content was higher in mixtures compost teas and B, having in common that both are made from goat manure, composted and fresh, respectively. Manures as raw material, are able to increase $\mathrm{N}$ of the by-products [45], effect desirable in their use as plant fertilizers. In general, micro and macronutrients were higher in mixture compost tea, with no significant effect of the aeration in the elaboration process. Mixture compost presented higher nutrient than grape marc compost, due the higher raw material diversity, explaining the higher extraction in compost tea brewing.

No pathogen were detected in the bio-products. Previous analyses indicated the absence of E. coli and Salmonella sp. in the compost used in teas brewing, suggesting that the sanitation was produced in composting process [45.46]. Besides the fresh manure utilized in bioslurry preparation, no pathogen were detected, which indicates the sanitization in the anaerobic process, in agree with Zhao and Liu [47].

PGPR determination in the products presented no significant differences with $\mathrm{H}_{2} \mathrm{O}$, suggesting that those bacteria were contributed by the dilution and brewing water. However higher content was found in the products, surely due to nutrient available to their growth, as it is demonstrated in total bacteria determination, where all teas presented significantly higher values than $\mathrm{H}_{2} \mathrm{O}$. There was no effect of aeration on bacterial content, while nonaerated teas presented higher fungus than aerated, in agree with Haggag and Saber [48], where denser biodiversity filamentous fungi and yeasts were found. However these authors also found higher bacteria in non-aerated, in contrast, in our results, no differences with aerated teas were found. Besides aerobic condition should benefits beneficial microorganisms content [49] no difference were found in this study.

According to Shrestha et al. [12], it is expected that aeration, benefits soluble metabolites and microbial growth, but in our results no differences were detected in bacterial content. It has been reported that high microbial content in the products, outcomes in a higher plant growth promotion, pathogens control, and soil biological activity and diversity with the consequent increase in crop growing [23,50,51]. However, several authors have found no differences between aerated and non-aerated compost teas, being growth promotion and pathogen control associated to the microflora existing in the extracts $[\mathbf{1 3}, \mathbf{1 4}]$. This indicates the contradictory information about brewing conditions and product quality, suggesting the high variability in their properties.

No toxicity effects were detected, and quite the opposite, all products and even well water increased root and hypocotyl elongation. The high EC, may cause negative effect on plants, which should be reduced by the progressive dilutions [52], but even non-diluted B did not affect $L$. sativa seeds germination and plant elongation, however presented the lowest values. Contrary to our findings, Carballo et al. [53] indicated that aerated teas conditions may result in lower toxicity than non-aerated, and dependents of application dilution. Our results demonstrated that compost teas can be used pure, in concordance with Morales-Corts et al. [54], while bioslurry is necessary to dilute, in agreed with FAO indications of $10 \%$ dilution for applications.

Plant biomass and sapling number analyses corroborates the highly variable properties and effect of bio-products in plants growth, justifying the contradictory and in some cases negative results found in bibliography $[\mathbf{5 5}, \mathbf{5 6}, \mathbf{5 7}]$. Bio-products effects were extremely variable on plant parameters, and as it was expected, application did not produced significant responses in compost treatments. The compost used as substrate was the same of that used in compost tea brewing, then all nutrients and microorganism was supposed to be already present in these treatments. Only bioslurry or commercial fertilizer would have been able to supplement the plant with different elements and beneficial organisms, explaining why they were the products with higher plant response. In Sand and commercial substrate, aerated compost teas presented no significant positive effect, possibly due an excessive increase in EC, affecting plant growth. It is necessary to establish reference parameters as guideline for quality evaluation. In this sense, Argentinean legislation has been recently promulgated (SCMA-SNSCA Res № 1/2019 [58], SENASA Res No 77/2019 [59], and SGADS Res № 19/2019 [60]), setting basic security and safely uses to incorporate this products in large scale productions.

However, compost tea and bioslurry increased pigments content and SPAD index respect to control, which is related to a higher plant nutrition quality. According to Schlemmer et al. [61], chlorophyll is related to nitrogen content in leafs, dependent on availability of this element in the substrate. In our study, bioslurry was the product with higher soluble $\mathrm{N}$, that would explain the effect observed in plants parameters, with no differences respect to a commercial fertilizer. Most of compost teas studies reported are related to biocontrol effect, while as fertilizer, other liquid products like bioslurry and vermicompost teas seems to be more effective, while compost tea results in an excellent complement [10, 62]. The combination 1:1 of aerated and non-aerated presented intermediate values considering only the teas, but in carotenoids of $I$. walleriana, this treatment produce the higher values, suggesting a slight complementation in the properties of both teas

Our results demonstrated that bioslurry designed for plant nutrition and not as a result of biogas generation as it is usually tested [15, 16], results in a high quality low-cost fertilizer reaching levels of synthetic commercial ones. Otherwise, compost teas showed variability, according to, highly dependent on compost origin and material used in composting, conditioning its potential as fertilizer. Also different respond related to plant species

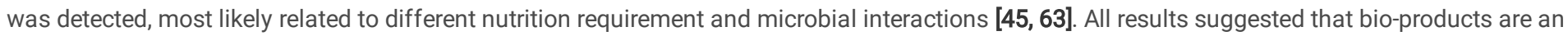

Page $7 / 16$ 
efficient and economical alternative to traditional products with similar yield. It is important to consider that each product presented different characteristics, which indicate its complementarity and combination in their application to increase productivity.

\section{Conclusion}

According to the characterization results, compost teas from mixtures compost presents better nutrient content than those brewed from a unique source compost. Methods of compost tea brewing (aerated and non-aerated) showed no considerable differences in plant biomass. Precautions must be taken, in order to decrease teas salinity, which can be regulated by dilution or lesser compost proportion in relation to water during brewing. Compost teas should be tested diluted as biofertilizer and also evaluate their potential to control fungal plant diseases. Diluted bioslurry appears to be more convenient as a biofertilizer to stimulate plant growing in pots. Compost could be used as a suitable substrate for flower plant production.

All results suggested that bio-products are an efficient, safe, ecological and economical alternative to traditional products with similar yield. It is important to consider that each product presented different characteristics, which indicate its complementarity and combination in their application to increase productivity.

\section{Declaration}

\section{Availability of data and materials}

All data generated and analyzed during this study are included in this published article as "public_data.xlsx" archive in supplementary material.

\section{Ethic declaration and competing interest}

None

\section{Funding}

Research was funded by the Fondo para la Investigación Científica y Tecnológica (FONCYT, PICT 2015-1727 to Ernesto Martín Uliarte), the agroecology network of INTA (REDAE) and the North Oasis Territorial Project (PRET) of INTA Mendoza.

\section{Contribution}

The authors declare that they have no competing interests. IFP supervise and design greenhouse experiments, performed toxicology test, determined pigments content, organized and statistically analyzed all data, and write manuscript; GP designed and guide greenhouse experiments; MA collected greenhouse and microorganism data; LM performed nutritional analyses; MF performed pathogen and PGPR analysis; and MU directed and supervise all experimental and publication process. All authors read and approved the final manuscript.

\section{Acknowledgment}

Authors are especially thankful with Gastón Alfredo Pinter for figures design assistance.

\section{Bibliography}

[1] Campos, E. V. R., Proença, P., Oliveira, J., Bakshi, M., Abhilash, P. C, Fraceto, L., 2018. Use of botanical insecticides for sustainable agriculture: Future perspectives. Ecol Indic, 105, 483-495 IN PRESS. https://doi.org/10.1016/j.ecolind.2018.04.038.

[2] Damalas, C. A., Eleftherohorinos, I. G., 2011. Pesticide exposure, safety issues, and risk assessment indicators. Int J Environ Res Public Health., 8(5):1402-19. https://doi.org/10.3390/ijerph8051402

[3] Savci, S., 2012. An agricultural pollutant: chemical fertilizer. International Journal of Environmental Science and Development, 3 (1): 77-80. https://doi.org/10.7763/IJESD.2012.V3.191

[4] Guo, W., Zhou, Y., Zhu, N., Hu, H., Shen, W., Huang, X., Zhang, T., Wu, P., Li, Z., 2018. On site composting of food waste: A pilot scale case study in China. Resour Conserv Recy, 132, 130-138. https://doi.org/10.1016/j.resconrec.2018.01.033

[5] Zhang, N., Hoadley, A., Patel, J., Lim, S., Li, C., 2017. Sustainable options for the utilization of solid residues from wine production. Waste Manage, 60:173-183. https://doi.org/10.1016/j.wasman.2017.01.006

[6] Eldridge, S.M., Yin Chan, K., Donovan, N.J. et al. Agronomic and economic benefits of green-waste compost for peri-urban vegetable production: implications for food security. Nutr Cycl Agroecosyst, 111, 155-173 (2018). https://doi.org/10.1007/s10705-018-9931-9 
[7] Moreno Casco, J., Mola Herrero, R., 2008. Compostaje. Ediciones Mundi-Prensa. Madrid, España. 570 pp.

[8] Epstein. E., 1997. The science of composting. CRC press. USA. 489 pp.

[9] Deepthi, P., Reddy, P. N., 2013. Compost teas-an organic source for crop disease manegement. International Journal of Innovative Biological Research, 2(1), 51-60.

[10] Kim, M. J., Shim, C. K., Kim, Y. K., Hong, S. J., Park, J. H., Han, E. J., Kim, J. H., Kim, S. C., 2015. Effect of Aerated Compost Tea on the Growth Promotion of Lettuce, Soybean, and Sweet Corn in Organic Cultivation. Plant Pathol J. 31(3):259-68. https://doi.org/10.5423/PPJ.0A.02.2015.0024

[11] Scheuerell, S., Mahaffee, W., 2002. Compost tea: principles and prospects for plant disease control. Compost Sci Util., 10 (4): $313-338$. https://doi.org/10.1080/1065657X.2002.10702095

[12] Shrestha, K., Shrestha, P., Walsh, K. B., Harrower, K. M., Midmore, D. J., 2011. Microbial enhancement of compost extracts based on cattle rumen content compost - characterisation of a system. Bioresour Technol, 102, 8027-8034. https://doi.org/10.1016/j.biortech.2011.06.076

[13] Marín, F, Santos, M., Dianez, F., Carretero, F., Gea, F. J., Yau, J. A., Navarro, M. J., 2013. Characters of compost teas from different sources and their suppressive effect on fungal phytopathogens. World J Microbiol Biotechnol., 29, 1371-1382. https://doi.org/10.1007/s11274-013-1300-x

[14] Scheuerell, S. J., Mahaffee, W. F., 2006. Variability Associated with Suppression of Gray Mold (Botrytis cinerea) on Geranium by Foliar Applications of Nonaerated and Aerated Compost Teas. Plant Dis, 90, 1201-1208. https://doi.org/10.1094/PD-90-1201

[15] Dahlin, J., Herbes, C., Nelles, M., 2015. Biogas digestate marketing: Qualitative insights into the supply side. Resour Conserv Recy., $104: 152-161$. https://doi.org/10.1016/j.resconrec.2015.08.013

[16] Koszel, M., Lorencowicz, E., 2015. Agricultural Use of Biogas Digestate as a Replacement Fertilizers. Agriculture and Agricultural Science Procedia, 7: 119-124. https://doi.org/10.1016/j.aaspro.2015.12.004

[17] Smith, E., Thavamani, P., Ramadass, K., Naidu, R., Srivastava, P., Megharaj, M., 2015. Remediation trials for hydrocarbon-contaminated soils in arid environments: Evaluation of bioslurry and biopiling techniques. International Biodeterioration \& Biodegradation, 101, 56-65.

Https://doi.org/10.1016/j.ibiod.2015.03.029

[18] Warnars, L., Oppenoorth, H., 2014. Bioslurry: A supreme fertilizer. Ed: Kelly Atkinson. Netherlands: Deltahage. ISBN 978-90-70435-07-3

[19] FAO, 2013. Los biopreparados para la producción de hortalizas en la agricultura urbana y periurbana. Supervisión técnica de Alberto Pantoja, Ph.D Oficial de Producción y Protección Vegetal. Available on-line: http://www.fao.org/3/a-i3360s.pdf

[20] Bonten, L. T. C., Zwart, K. B., Rietra, R. P. J. J., Postma, R, De Haas, M. J. G., Nysingh, S. L., 2014. Bio-slurry as fertilizer: is bio-slurry from household digesters a better fertilizer than manure?: a literature review (No. 2519). Alterra, Wageningen-UR. Alterra report 2519. 46 pp

[21] Groot, L. D., Bogdanski, A., 2013. Bioslurry = brown gold? A review of scientific literature on the co-product of biogas production. Food and Agriculture Organization of the United Nations (FAO). http://www.fao.org/3/a-i3441e.pdf

[22] Mortola, N., Romaniuk, R., Cosentino, V., Eiza, M., Carfagno, P., Rizzo, P., Bres, P., Riera, N., Roba, N., Butti, M., Sainz, D., Brutti, L., 2019. Potential Use of a Poultry Manure Digestate as a Biofertiliser: Evaluation of Soil Properties and Lactuca sativa Growth. Pedosphere, 29 : 60-69.

https://doi.org/10.1016/S1002-0160(18)60057-8.

[23] St. Martin, C. C. G., 2014. Potential of compost tea for suppressing plant diseases. CAB Reviews, 9 (32), 1-38. http://dx.doi.org/10.1079/PAVSNNR20149032

[24] St Martin, C. C. G., Brathwaite, R. A. I., 2012. Compost and compost tea: Principles and prospects as substrates and soil-borne disease management strategies in soil-lessvegetable production. Biol Agric Hortic, 28:1, 1-33. http://dx.doi.org/10.1080/01448765.2012.671516

[25] Tian, G., Zhang, W., Dong, M., Yang, B., Zhu, R., Yin, F., Zhao, X., Wang, Y., Xiao, W., Wang, Q., Cui, X., 2017. Metabolic pathway analysis based on high-throughput sequencing in a batch biogas production process. Energy, 139: 571-579. http://dx.doi.org/10.1016/j.energy.2017.08.003

[26] On, A., Wong, F., Ko, Q., Tweddell, R. J., Antoun, H., Avis, T. J., 2015. Antifungal effects of compost tea microorganisms on tomato pathogens. Biol Control, 80: 63-69. http://dx.doi.org/10.1016/j.biocontrol.2014.09.017

[27] Milinković, M., Lalević, B., Jovičić-Petrović, J., Golubović-Ćurguz, V., Kljujev, I., Raičević, V., 2019. Biopotential of compost and compost products derived from horticultural waste-Effect on plant growth and plant pathogens' suppression. Process Saf Environ., 121: 299-306.

https://doi.org/10.1016/j.psep.2018.09.024

Page $9 / 16$ 
[28] Muscolo, A., Papalia, T., Settineri, G., Mallamaci, C., Jeske-Kaczanowska, A., 2018. Are raw materials or composting conditions and time that most influence the maturity and/or quality of composts? Comparison of obtained composts on soil properties. J Clean Prod, 195: 93-101.

https://doi.org/10.1016/j.jclepro.2018.05.204

[29] INTA: Instituto Nacional de Tecnología Agropecuaria, Argentina. 2003. Estudio sobre la caracterización de la producción florícola en la República Argentina, pp: 87. https://inta.gob.ar/documentos/estudio-sobre-la-caracterizacion-de-la-produccion-floricola-en-la-republica-argentina

[30] Maher, M., Prasad, M., Raviv, M., 2008. Organic soilless media components. Soilless Culture: Theory and Practice, $459-504$.

https://doi.org/10.1016/b978-044452975-6.50013-7

[31] Abad, M., Noguera, P., Carrión C., 2004. Los sustratos en los cultivos sin suelo. En: Tratado de cultivo sin suelo. pp. 113-158. Urrestarazu Gavilán, M. (Ed.). Ediciones Mundi-Prensa, Madrid.

[32] Abad, M., Noguera, P., Burés, S., 2001. National inventory of organic wastes for use as growing media for ornamental potted plant production: case study in Spain. Bioresource Technology, 77(2), 197-200. https://doi.org/10.1016/s0960-8524(00)00152-8

[33] Raviv, M., Wallach, R., Silver, A., Bar-Tal, A., 2002. Substrates and their analysis. In: Hydroponic Production of vegetables and ornamental. pp. 25102. Sawas, D. and Passam, H. (Eds). Embryo Publications, Greece.

[34] Mendoza Hernandez, D. D. J., 2010. Vermicompost y compost de residuos hortícolas como componentes de sustratos para la producción de planta ornamental y aromática. Caracterización de los materiales y respuesta vegetal. Universitat Politècnica de València.

https://doi.org/10.4995/Thesis/10251/8685

[35] Benito, M., Masaguer, A., De Antonio, R., Moliner A., 2005. Use of pruning waste compost as a component in soilless growing media. Bioresource Technol., 96 (5), 597-603. https://doi.org/10.1016/j.biortech.2004.06.006.

[36] Funes Pinter, I., Salomon, M. V., Berli, F, Gil, R., Bottini, R., Piccoli, P., 2018. Plant growth promoting rhizobacteria alleviate stress by AsIll in grapevine. Agr Ecosyst Environ, 267: 100-108. https://doi.org/10.1016/j.agee.2018.08.015

[37] Bremmer, J. and Mulvaney C., 1982. Nitrogen total. En: Methods of soil analysis. Vol 2. Chemical and microbiological properties. American Society of Agronomy and Soil Science. Madison, Wisconsin, USA, pp. 595-624.

[38] Sadzawka, A., Carrasco, M. A., Grez, R., Mora, M. L., 2005. Métodos de análisis de compost. Instituto de Investigaciones Agropecuarias (INIA), Serie Actas $N^{\circ} 30$, Santiago, Chile. 142 p.

[39] TMECC, 2002. Test methods for the examination of composting and compost. US Compost Council.

[40] Frioni, L., 2005. In: Microbiología: Básica, Ambiental Y Agrícola. Facultad de Agronomía, Universidad de la República Uruguay, pp. $363-383$.

[41] Alef, K., Nannipieri, P., 1995. Methods in applied soil microbiology and biochemistry. London; San Diego: Academic Press

[42] US EPA: US Environmental Protection Agency, 1996 Ecologicaleffects test guidelines. Seed germination/root elongation toxicitytest. OPPTS 850.4200

[43] Berli, F.J., Moreno, D., Piccoli, P., Hespanhol-Viana, L., Silva, M.F., Bressan-Smith, R., Cavagnaro, J.B., Bottini, R., 2010. Abscisic acid is involved in the response of grape (Vitis vinifera L.) cv. malbec leaf tissues to ultraviolet-b radiation by enhancing ultraviolet-absorbing compounds, antioxidant enzymes and membrane sterols. Plant Cell Environ, 33 (1), 1-10. https://doi.org/10.1111/j.1365-3040.2009.02044.x.

[44] Islam, M. K ., Yaseen, T., Traversa, A., Ben Kheder, M., Brunetti, G., Cocozza, C., 2016. Effects of the main extraction parameters on chemical and microbial. Waste Manage, 52: 62-68. http://dx.doi.org/10.1016/j.wasman.2016.03.042

[45] Pant, A.P., Radovich, T.J.K., Hue, N.V., Paull, R.E., 2012. Biochemical properties of compost tea associated with compost quality and effects on pak choi growth. Sci Hortic (Amst.), 148, 138-146. https://doi.org/10.1016/j.scienta.2012.09.019.

[46] Thassitou, P. K., Arvanitoyannis, I. S., 2001. Bioremediation: a novel approach to food waste management. Trends Food Sci Tech, 12 : $185-196$. https://doi.org/10.1016/S0924-2244(01)00081-4

[47] Zhao, Q., Liu, Y., 2019. Is anaerobic digestion a reliable barrier for deactivation of pathogens in biosludge? Sci Total Environ, 668, $893-902$. https://doi.org/10.1016/j.scitotenv.2019.03.063

[48] Haggag, W. M., Saber, M. S. M., 2007. Suppression of early blight on tomato and purple blight on onion by foliar speays of aerated and nonaerated compost teas. J. Food Agric Environ, 5:302-309.

[49] Ingham, E., 2005. The compost tea brewing manual. US Printings, Soil Foodweb Incorporated, Oregon.

Page $10 / 16$ 
[50] Haller, H., Jonsson, A., Montenegro Rayo, K., Dávila López, A., 2016. Microbial transport of aerated compost tea organisms in clay loam and sandy loam - A soil column study. International Biodeterioration \& Biodegradation, 106, 10-15. https://doi.org/10.1016/j.ibiod.2015.10.002.

[51] Abou-El-Hassan, S., Abdrabbo, M. A. A., Desoky, A. H., 2014. Enhancing Organic Production of Cucumber by using Plant Growth Promoting Rhizobacteria and Compost Tea under Sandy Soil Condition. Research Journal of Agriculture and Biological Sciences, 10(2), 162-169.

[52] Milinkovic, M., Lalevic, B., Jovicic-Petrovic, J., Golubovic-Curguz, V., Kljujev, I., Vera Raičevic, V., 2019. Biopotential of compost and compost products derived from horticultural waste-Effect on plant growth and plant pathogens' suppression. Process Saf Environ., 121: $299-306$.

https://doi.org/10.1016/j.psep.2018.09.024

[53] Carballo, T., Gil, M. V., Calvo, L. F., Morán, A., 2009. The Influence of Aeration System, Temperature and Compost Origin on the Phytotoxicity of Compost Tea. Compost Sci UtiL, 17:2, 127-139. https://doi.org/10.1080/1065657X.2009.10702411

[54] Morales-Corts, M. R, Pérez-Sánchez, R., Gómez-Sánchez, M. Á., 2018. Efficiency of garden waste compost teas on tomato growth and its suppressiveness against soilborne pathogens. Scientia Agricola, 75(5), 400-409. https://doi.org/10.1590/1678-992x-2016-0439

[55] Eudoxie, G., Martin, M., 2019. Compost Tea Quality and Fertility, Organic Fertilizers - History, Production and Applications. IntechOpen. https://doi.org/10.5772/intechopen.86877

[56] Santiago-López, G., Preciado-Rangel, P., Sánchez-Chavez, E., Esparza-Rivera, J. R., Fortis-Hernández, M., Moreno-Reséndez, A., 2016. Organic nutrient solutions in production and antioxidant capacity of cucumber fruits. Emir J Food Agr, 28(7):518-521. https://doi.org/10.9755/ejfa.2016-01083

[57] Abou-El-Hassan, S., El-Behairy, U. A., Selim, S. M., Abou-Hadid, A. F., 2008. Effect of compost tea as organic nutrient solution for cantaloupe production grown in nutrient film technique. Egypt J Hort, 35:41-58.

[58] SCMA y SNSCA: Secretaría de Control y Monitoreo Ambiental y Servicio Nacional de Sanidad y Calidad Agroalimentaria. Argentina. Resolución Conjunta No 1/2019. Marco Normativo para la Producción, Registro y Aplicación de Compost.

[59] SENASA: Servicio Nacional de Sanidad y Calidad Agroalimentaria. Argentina. Resolución No 77/2019. Programa de Residuos Orgánicos Regulados.

[60] SGADS: Secretaría de Gobierno de Ambiente y Desarrollo Sustentable. Argentina. Resolución No 19/2019. Norma técnica para la aplicación agrícola de digerido proveniente de plantas de digestión anaeróbica

[61] Schlemmer, M., Gitelson, A., Schepers, J., Ferguson, R., Peng, Y., Shanahan, J., Rundquist, D., 2013. Remote estimation of nitrogen and chlorophyll contents in maize at leaf and canopy levels. International Journal of Applied Earth Observation and Geoinformation, 25, 47-54.

https://doi.org/10.1016/j.jag.2013.04.003

[62] Ismael, D. P, St. Martin, C. C. G., Eudoxie, G. D., Rouse-Millet, J., 2013. Combined effects and relationships of compost tea, fertiliser, and glomus intraradices inoculated substrate on tomato seedling quality. Proceedings of the Caribbean Food Crops Society, 49:362-372.

[63] Marín, F., Diánez, F., Gea, F. J., Navarro, M. J., Santos, M., 2015. Effect of Compost Tea on Plant Growth and Plant Disease Management CAB International 2015. Sustainable Crop Disease Management using Natural Products, 14, 234-264.

\section{Tables}

Table 1: ANOVA and Kruskal-Wallis (only in P content) test of the bioproducts physicochemical characteristics and nutrients. AM: aerated mixture compost tea; AG: aerated grape marc compost tea; NAM: non-aerated mixture residues compost tea; NAG: non-aerated grape marc compost tea; B: bioslurry; $\mathrm{H}_{2} \mathrm{O}$ : free chloride water (well water). Values expressed as medium \pm standard deviation. 


\begin{tabular}{|c|c|c|c|c|c|c|c|c|c|c|c|c|}
\hline \multirow{3}{*}{$\begin{array}{l}\text { Bio } \\
\text { AM }\end{array}$} & \multirow{3}{*}{$\begin{array}{l}\mathrm{pH} \\
8.25\end{array}$} & \multirow[b]{3}{*}{ $\pm 0.03^{d}$} & \multirow{2}{*}{\multicolumn{2}{|c|}{$\begin{array}{l}\text { EC } \\
\mu \mathrm{S} \mathrm{cm}^{-1}\end{array}$}} & \multirow{2}{*}{\multicolumn{2}{|c|}{$\begin{array}{l}\mathrm{N}-\mathrm{NO}_{3}^{-} \\
\mathrm{mg} \mathrm{L}^{-1}\end{array}$}} & \multicolumn{2}{|c|}{$\mathrm{N}-\mathrm{NH}_{4}^{+}$} & \multicolumn{2}{|l|}{$\mathbf{P}$} & \multirow[t]{2}{*}{$\mathrm{K}$} & \\
\hline & & & & & & & & & & & & \\
\hline & & & 2.29 & $\pm 0.50^{c}$ & 6.32 & $\pm 0.76^{b c}$ & 22.60 & $\pm 4.76^{b c}$ & 27.45 & $\pm 3.32^{\mathrm{cd}}$ & 637.00 & $\pm 9.96^{\mathrm{e}}$ \\
\hline$A G$ & 7.44 & $\pm 0.04^{\mathrm{c}}$ & 2.13 & $\pm 0.42^{c}$ & 2.76 & $\pm 0.16^{\mathrm{ab}}$ & 17.60 & $\pm 3.45^{\mathrm{ab}}$ & 19.02 & $\pm 0.23^{\mathrm{b}}$ & 494.67 & $\pm 12.66^{d}$ \\
\hline NAM & 7.32 & $\pm 0.03^{b}$ & 2.52 & $\pm 0.05^{c}$ & 6.43 & $\pm 0.24^{b c}$ & 23.13 & $\pm 3.44^{b c}$ & 30.12 & $\pm 0.47^{d}$ & 635.50 & $\pm 3.77^{\mathrm{e}}$ \\
\hline NAG & 6.98 & $\pm 0.07^{a}$ & 2.26 & $\pm 0.06^{c}$ & 3.56 & $\pm 0.03^{a b}$ & 3.00 & $\pm 2.04^{\mathrm{ab}}$ & 24.69 & $\pm 1.95^{\mathrm{c}}$ & 459.00 & $\pm 22.40^{\mathrm{c}}$ \\
\hline B & 8.42 & $\pm 0.02^{\mathrm{e}}$ & 1.65 & $\pm 0.01^{b}$ & 7.86 & $\pm 1.06^{c}$ & 40.77 & $\pm 3.41^{\mathrm{c}}$ & 2.95 & $\pm 0.01^{a}$ & 143.45 & $\pm 3.50^{\mathrm{b}}$ \\
\hline $\mathrm{H}_{2} \mathrm{O}$ & 8.34 & $\pm 0.08^{\mathrm{de}}$ & 1.05 & $\pm 0.06^{a}$ & 2.21 & $\pm 0.43^{a}$ & 0.40 & $\pm 0.05^{\mathrm{a}}$ & 0.20 & $\pm 0.01^{a}$ & 3.20 & $\pm 1.10^{\mathrm{a}}$ \\
\hline
\end{tabular}

*different letters indicate significant differences $(p<0.05)$

Table 2: ANOVA test of bioproducts macro and micronutrients content. AM: aerated mixture compost tea; AG: aerated grape marc compost tea; NAM: non-aerated mixture residues compost tea; NAG: non-aerated grape marc compost tea; B: bioslurry; $\mathrm{H}_{2} \mathrm{O}$ : free chloride water (well water). Values expressed as medium \pm standard deviation.

\begin{tabular}{|c|c|c|c|c|c|c|c|c|c|c|c|c|c|c|}
\hline \multirow[t]{2}{*}{ Bio } & \multicolumn{2}{|l|}{$\mathrm{Ca}$} & \multicolumn{2}{|l|}{$\mathrm{Mg}$} & \multicolumn{2}{|l|}{$\mathrm{Na}$} & \multicolumn{2}{|l|}{$\mathrm{Fe}$} & \multicolumn{2}{|l|}{$\mathrm{Cu}$} & \multicolumn{2}{|l|}{$\mathrm{Zn}$} & \multicolumn{2}{|l|}{ Mn } \\
\hline & $\mathrm{mg} \mathrm{L}^{-1}$ & & & & & & & & & & & & & \\
\hline AM & 149.70 & $\pm 36.56^{\mathrm{abc}}$ & 51.95 & $\pm 4.29^{b c}$ & 143.67 & $\pm 5.11^{d}$ & 0.10 & $\pm 0.06^{d}$ & 0.02 & $\pm 0.04^{\mathrm{a}}$ & 0.03 & $\pm 0.01^{c}$ & 0.04 & $\pm 0.00^{c}$ \\
\hline AG & 145.97 & $\pm 5.19^{a b c}$ & 28.33 & $\pm 0.76^{a}$ & 119.33 & $\pm 2.75^{c}$ & 0.07 & $\pm 0.01^{b}$ & 0.05 & $\pm 0.05^{\mathrm{a}}$ & 0.02 & $\pm 0.01^{\mathrm{abc}}$ & 0.13 & $\pm 0.02^{d}$ \\
\hline NAM & 238.17 & $\pm 46.87^{c}$ & 64.93 & $\pm 9.48^{c}$ & 145.50 & $\pm 4.00^{\mathrm{d}}$ & 0.15 & $\pm 0.01^{d}$ & 0.04 & $\pm 0.04^{\mathrm{a}}$ & 0.02 & $\pm 0.01^{b c}$ & 0.16 & $\pm 0.00^{e}$ \\
\hline NAG & 204.57 & $\pm 15.20^{b c}$ & 34.50 & $\pm 1.32^{\mathrm{abc}}$ & 114.33 & $\pm 5.53^{c}$ & 0.10 & $\pm 0.01^{\mathrm{c}}$ & 0.03 & $\pm 0.03^{\mathrm{a}}$ & 0.01 & $\pm 0.00^{\mathrm{abc}}$ & 0.03 & $\pm 0.01^{b c}$ \\
\hline B & 113.00 & $\pm 93.97^{a}$ & 30.00 & $\pm 0.01^{a b}$ & 103.17 & $\pm 0.29^{b}$ & 0.06 & $\pm 0.02^{\mathrm{ab}}$ & 0.04 & $\pm 0.07^{a}$ & 0.03 & $\pm 0.01^{c}$ & 0.01 & $\pm 0.02^{\mathrm{ab}}$ \\
\hline $\mathrm{H}_{2} \mathrm{O}$ & 82.45 & $\pm 70.92^{\mathrm{a}}$ & 25.32 & $\pm 18.74^{\mathrm{a}}$ & 44.67 & $\pm 3.75^{\mathrm{a}}$ & 0.04 & $\pm 0.02^{\mathrm{a}}$ & 0.00 & $\pm 0.01^{\mathrm{a}}$ & 0.01 & $\pm 0.00^{\mathrm{a}}$ & 0.00 & $\pm 0.00^{\mathrm{a}}$ \\
\hline
\end{tabular}

*different letters indicate significant differences $(p<0.05)$

Table 3: Non-parametric Kruskal-Wallis analysis of microorganism content in bio-products. AM: aerated mixture compost tea; AG: aerated grape marc compost tea; NAM: non-aerated mixture residues compost tea; NAG: non-aerated grape marc compost tea; $\mathrm{B}$ : bioslurry; $\mathrm{H}_{2} \mathrm{O}$ : free chloride water (well water). TVAB and TVAF: Total viable aerobic bacteria and fungus, respectively. Values expressed as medium \pm standard deviation.

\begin{tabular}{|lllllllllll|}
\hline Bio & TVAB & & TVAF & \multicolumn{3}{c}{ Nitrifying } & $\mathrm{N}_{2}$ fixing & Ammonifying \\
\cline { 2 - 11 } & $\log _{10} \mathrm{CFU} \mathrm{mL}^{-1}$ & & & & & & & & & \\
\hline AM & 4.17 & $\pm 0.28^{\mathrm{bc}}$ & 0.10 & $\pm 0.17^{\mathrm{ab}}$ & 0.96 & $\pm 0.58^{\mathrm{bc}}$ & 1.22 & $\pm 0.11^{\mathrm{a}}$ & 2.23 & $\pm 1.41^{\mathrm{a}}$ \\
\hline AG & 4.26 & $\pm 0.28^{\mathrm{bc}}$ & 0.51 & $\pm 0.29^{\mathrm{abc}}$ & 0.10 & $\pm 0.17^{\mathrm{ab}}$ & 4.07 & $\pm 4.07^{\mathrm{a}}$ & 2.03 & $\pm 1.76^{\mathrm{a}}$ \\
\hline NAM & 4.21 & $\pm 0.26^{\mathrm{bc}}$ & 1.00 & $\pm 0.48^{\mathrm{c}}$ & 1.23 & $\pm 0.52^{\mathrm{c}}$ & 3.99 & $\pm 0.16^{\mathrm{a}}$ & 2.45 & $\pm 0.05^{\mathrm{a}}$ \\
\hline NAG & 4.47 & $\pm 0.20^{\mathrm{c}}$ & 0.78 & $\pm 0.42^{\mathrm{bc}}$ & 0.43 & $\pm 0.50^{\mathrm{abc}}$ & 4.15 & $\pm 4.15^{\mathrm{a}}$ & 2.89 & $\pm 0.36^{\mathrm{a}}$ \\
\hline B & 3.90 & $\pm 0.22^{\mathrm{ab}}$ & 0.00 & $\pm 0.00^{\mathrm{a}}$ & 0.70 & $\pm 0.61^{\mathrm{abc}}$ & 4.10 & $\pm 0.17^{\mathrm{a}}$ & 1.56 & $\pm 0.09^{\mathrm{a}}$ \\
\hline $\mathrm{H}_{2} \mathrm{O}$ & 2.10 & $\pm 1.83^{\mathrm{a}}$ & 0.00 & $\pm 0.00^{\mathrm{a}}$ & 0.00 & $\pm 0.00^{\mathrm{a}}$ & 3.15 & $\pm 0.65^{\mathrm{a}}$ & 1.56 & $\pm 0.83^{\mathrm{a}}$ \\
\hline
\end{tabular}

*different letters indicate significant differences $(p<0.05)$

Table 4: Non-parametric analysis of pathogenic and beneficial microorganism content in bio-products. AM: aerated mixture compost tea; AG: aerated grape marc compost tea; NAM: non-aerated mixture residues compost tea; NAG: non-aerated grape marc compost tea; $\mathrm{B}$ : bioslurry; $\mathrm{H}_{2} \mathrm{O}$ : free chloride 
water (well water). Values expressed as medium \pm standard deviation.

\begin{tabular}{|llllllllll|}
\hline Bio & \multicolumn{2}{l}{ TColiforms } & E. coli & Salmonella sp. & P. aeruginosa & \multicolumn{2}{l|}{ B. cereus } \\
\hline AM & 3.44 & $\pm 0.79^{\mathrm{c}}$ & nd & nd & 1.90 & $\pm 0.16^{\mathrm{a}}$ & 2.02 & $\pm 1.93^{\mathrm{a}}$ \\
AG & 2.18 & $\pm 0.14^{\mathrm{abc}}$ & nd & nd & 0.59 & $\pm 1.03^{\mathrm{a}}$ & 0.57 & $\pm 0.98^{\mathrm{a}}$ \\
NAM & 2.29 & $\pm 0.10 \mathrm{a}^{\mathrm{bc}}$ & nd & nd & 0.33 & $\pm 0.58^{\mathrm{a}}$ & 1.73 & $\pm 1.50^{\mathrm{a}}$ \\
NAG & 2.35 & $\pm 0.35^{\mathrm{bc}}$ & nd & nd & 1.00 & $\pm 0.89^{\mathrm{a}}$ & 2.23 & $\pm 0.50^{\mathrm{a}}$ \\
B & 0.97 & $\pm 0.85^{\mathrm{a}}$ & nd & nd & 1.41 & $\pm 1.28^{\mathrm{a}}$ & 0.63 & $\pm 1.10^{\mathrm{a}}$ \\
$\mathrm{H}_{2} \mathrm{O}$ & 1.40 & $\pm 0.78^{\mathrm{ab}}$ & nd & nd & 0.62 & $\pm 0.87^{\mathrm{a}}$ & 2.00 & $\pm 0.00^{\mathrm{a}}$ \\
\hline
\end{tabular}

*different letters indicate significant differences $(p<0.05)$, nd: not detected

Table 5: ANOVA of pigments content in leaves of Impatiens walleriana and Petunia hibrida. Carot: carotenoids; TChl: total chlorophyll; AM: aerated mixture residues compost tea; NAM: non-aerated residues mixture compost tea; A-NAM: mixture 1:1 of AM and NAM; B: bioslurry; F: commercial fertilizer; $\mathrm{H}_{2} \mathrm{O}$ : well water (Control).

\begin{tabular}{|c|c|c|c|c|c|c|c|c|c|}
\hline \multirow[t]{3}{*}{ Substrate } & \multirow[t]{3}{*}{ Product } & \multicolumn{4}{|c|}{ I. walleriana } & \multicolumn{4}{|c|}{ P. hibrida } \\
\hline & & \multicolumn{2}{|l|}{ Carot } & \multicolumn{2}{|l|}{ TChl } & \multicolumn{2}{|l|}{ Carot } & \multicolumn{2}{|l|}{ TChl } \\
\hline & & \multicolumn{4}{|c|}{$\mu \mathrm{g} \mathrm{mg} \mathrm{g}^{-1}$} & \multicolumn{4}{|c|}{$\mu \mathrm{g} \mathrm{mg}{ }^{-1}$} \\
\hline \multirow[t]{6}{*}{ Sand } & AM & 13.58 & $\pm 3.89^{\text {defgh }}$ & 75.03 & $\pm 22.41^{\mathrm{bcd}}$ & 14.51 & $\pm 2.35^{\text {bcdef }}$ & 49.03 & $\pm 4.52^{\mathrm{abc}}$ \\
\hline & NAM & 12.57 & $\pm 4.48^{\text {bcdefg }}$ & 76.39 & $\pm 27.86^{\mathrm{bcd}}$ & 17.31 & $\pm 1.96^{f}$ & 45.41 & $\pm 18.73^{\mathrm{abc}}$ \\
\hline & A-NAM & 16.16 & $\pm 2.08^{f g h}$ & 93.94 & $\pm 19.40^{\mathrm{cd}}$ & 14.86 & $\pm 4.25^{\text {bcdef }}$ & 38.31 & $\pm 6.70^{\mathrm{ab}}$ \\
\hline & B & 17.66 & $\pm 2.93^{h}$ & 99.85 & $\pm 15.42^{\text {cde }}$ & 16.14 & $\pm 3.13^{\text {cdef }}$ & 52.14 & $\pm 8.21^{\mathrm{abcd}}$ \\
\hline & $\mathbf{F}$ & 11.49 & $\pm 5.02^{\text {abcde }}$ & 67.43 & $\pm 31.22^{\mathrm{abc}}$ & 14.29 & $\pm 0.81^{\text {bcdef }}$ & 70.32 & $\pm 11.18^{\text {defg }}$ \\
\hline & $\mathrm{H}_{2} \mathrm{O}$ & 10.70 & $\pm 3.35^{\text {abcde }}$ & 64.94 & $\pm 31.13^{\mathrm{abc}}$ & 12.86 & $\pm 2.84^{\mathrm{abc}}$ & 31.79 & $\pm 3.70^{\mathrm{a}}$ \\
\hline \multirow[t]{6}{*}{ Compost } & AM & 12.87 & $\pm 6.90^{\text {cdefg }}$ & 96.19 & $\pm 54.23^{\text {cde }}$ & 16.29 & $\pm 1.98^{\mathrm{def}}$ & 73.66 & $\pm 17.06^{\mathrm{efgh}}$ \\
\hline & NAM & 14.25 & $\pm 2.78^{\mathrm{efgh}}$ & 86.13 & $\pm 30.84^{\text {cde }}$ & 14.13 & $\pm 2.98^{\mathrm{bcdef}}$ & 62.60 & $\pm 22.96^{\text {cdef }}$ \\
\hline & A-NAM & 14.75 & $\pm 2.47^{\mathrm{efgh}}$ & 109.89 & $\pm 24.37^{\mathrm{de}}$ & 14.53 & $\pm 3.39^{\mathrm{bcdef}}$ & 61.39 & $\pm 27.17^{\text {cdef }}$ \\
\hline & B & 15.36 & $\pm 7.57^{\text {bcdefg }}$ & 121.97 & $\pm 53.03^{\mathrm{e}}$ & 17.41 & $\pm 2.87^{f}$ & 91.78 & $\pm 23.35^{h}$ \\
\hline & $F$ & 16.42 & $\pm 2.30^{\mathrm{gh}}$ & 114.45 & $\pm 15.06^{\mathrm{e}}$ & 16.42 & $\pm 4.82^{\mathrm{ef}}$ & 86.30 & $\pm 34.01^{\mathrm{gh}}$ \\
\hline & $\mathrm{H}_{2} \mathrm{O}$ & 16.56 & $\pm 2.85^{\mathrm{gh}}$ & 109.70 & $\pm 22.70^{\mathrm{de}}$ & 14.89 & $\pm 2.44^{\text {bcdef }}$ & 60.11 & $\pm 17.43^{\text {cdef }}$ \\
\hline \multirow[t]{6}{*}{ Commercial } & AM & 7.17 & $\pm 1.04^{\mathrm{a}}$ & 32.82 & $\pm 10.07^{a}$ & 12.66 & $\pm 1.63^{\mathrm{ab}}$ & 49.55 & $\pm 7.46^{\mathrm{abcd}}$ \\
\hline & NAM & 9.31 & $\pm 4.27^{\mathrm{abcd}}$ & 44.71 & $\pm 20.45^{\mathrm{ab}}$ & 13.59 & $\pm 2.46^{\text {abcde }}$ & 53.94 & $\pm 6.19^{\text {bcde }}$ \\
\hline & A-NAM & 8.38 & $\pm 1.21^{\mathrm{abc}}$ & 38.30 & $\pm 12.09^{a}$ & 14.16 & $\pm 0.83^{\text {bcdef }}$ & 54.91 & $\pm 11.74^{\text {bcde }}$ \\
\hline & B & 11.82 & $\pm 1.75^{\text {bcdef }}$ & 68.09 & $\pm 16.04^{\mathrm{abc}}$ & 12.97 & $\pm 1.07^{\mathrm{abcd}}$ & 66.02 & $\pm 11.93^{\text {cdefg }}$ \\
\hline & $F$ & 8.74 & $\pm 2.99^{\mathrm{abc}}$ & 37.28 & $\pm 16.90^{\mathrm{a}}$ & 15.36 & $\pm 2.78^{\text {bcdef }}$ & 80.66 & $\pm 17.98^{\mathrm{fgh}}$ \\
\hline & $\mathrm{H}_{2} \mathrm{O}$ & 8.27 & $\pm 3.78^{\mathrm{ab}}$ & 36.15 & $\pm 38.56^{\mathrm{a}}$ & 10.28 & $\pm 1.00^{\mathrm{a}}$ & 36.05 & $\pm 11.17^{a b}$ \\
\hline
\end{tabular}

*different letters indicate significant differences $(p<0.05)$ 

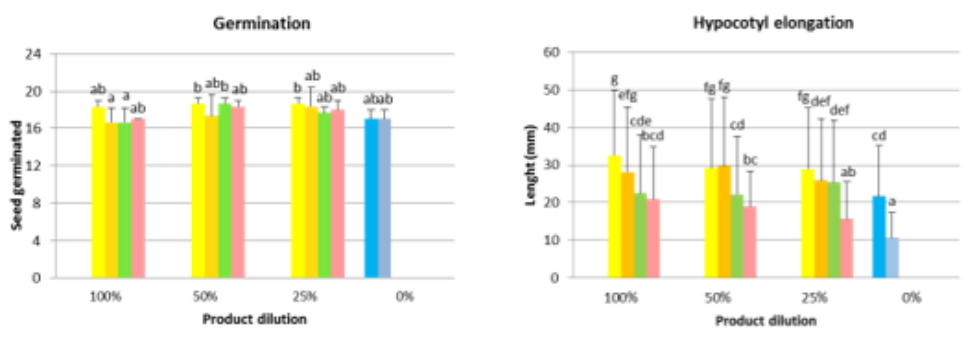

C

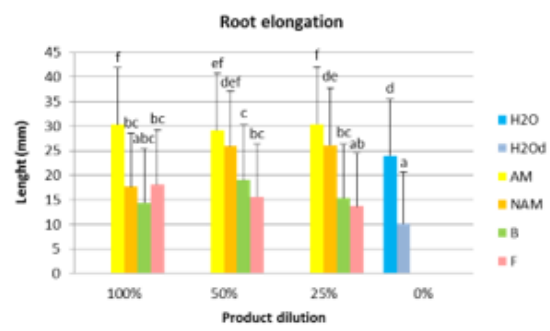

\section{Figure 1}

ANOVA (LSD Fisher, p>0.05) of bio-products toxicology test on L. sativa seeds, growing on Petri plates, in darkness, at $20{ }^{\circ} \mathrm{C}$ during 5 days. A: Total germination in different product dilution; B: Hypocotyl elongation of seedlings; and C: root elongation of seedlings. $\mathrm{H} 2 \mathrm{O}$ : well water; $\mathrm{H} 2 \mathrm{Od}$ : distilled water; AM: aerated mixture residues compost tea; NAM: non-aerated residues mixture compost tea; B: bioslurry; and F: commercial fertilizer.

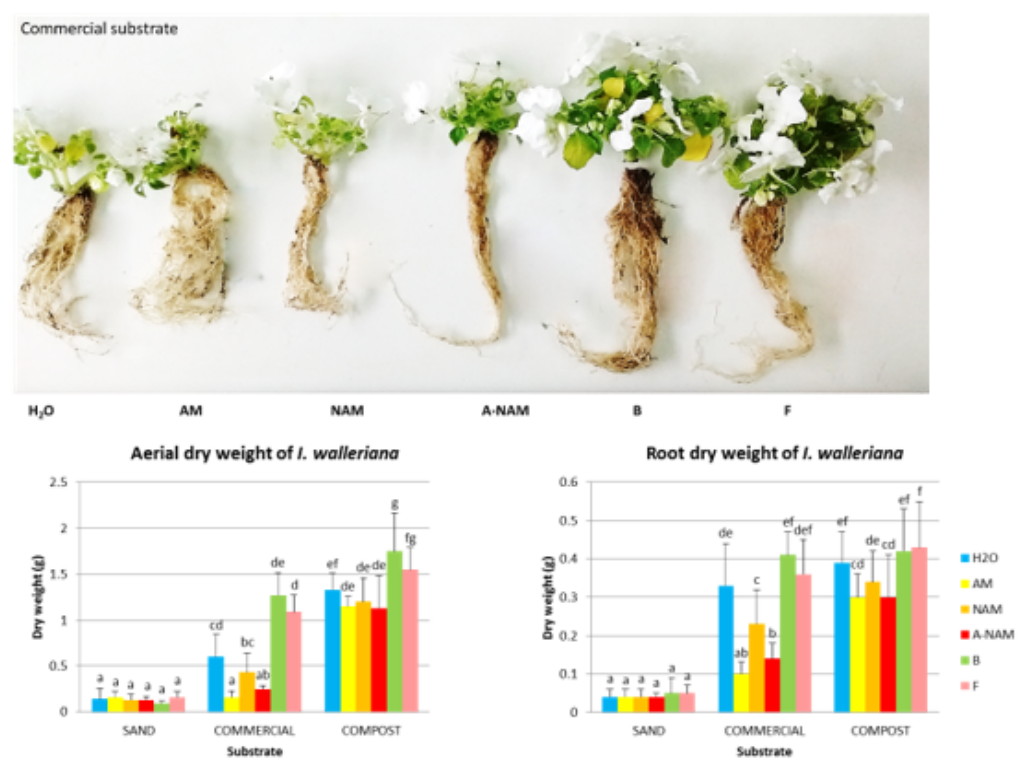

\section{Figure 2}

ANOVA (LSD Fisher, p>0.05) of bio-products application on Impatiens walleriana dry biomass. A: I walleriana irrigated with different bio-products; B: Aerial dry weight; and C: root dry weight. H2O: well water (Control); AM: aerated mixture residues compost tea; NAM: non-aerated residues mixture compost tea; A-NAM: mixture 1:1 of AM and NAM; B: bioslurry; and F: commercial fertilizer. 

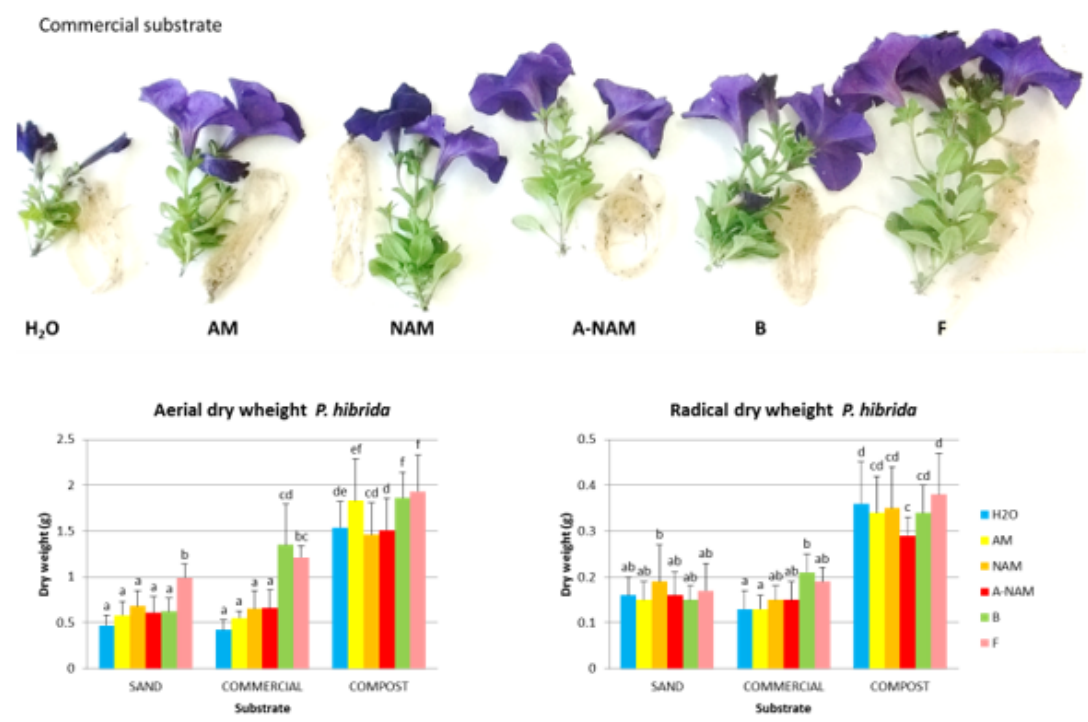

Figure 3

ANOVA (LSD Fisher, p>0.05) of bio-products application on Petunia hibridadry biomass. A: P. hibrida irrigated with different bio-products; B: Aerial dry weight; and C: root dry weight. H2O: well water (Control); AM: aerated mixture residues compost tea; NAM: non-aerated residues mixture compost tea; A-NAM: mixture 1:1 of AM and NAM; B: bioslurry; and F: commercial fertilizer.
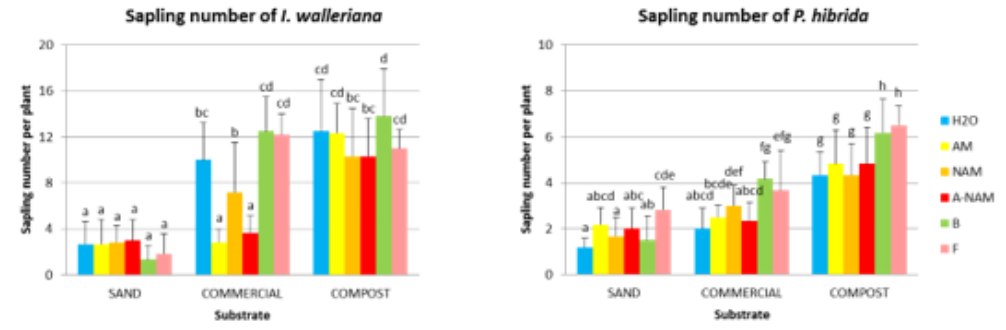

Figure 4

ANOVA of sapling number in Impatiens walleriana and Petunia hibrida, growing in different substrates and irrigated with bio-products. H2O: well water (Control); AM: aerated mixture residues compost tea; NAM: non-aerated residues mixture compost tea; A-NAM: mixture 1:1 of AM and NAM; B: bioslurry; and F: commercial fertilizer.
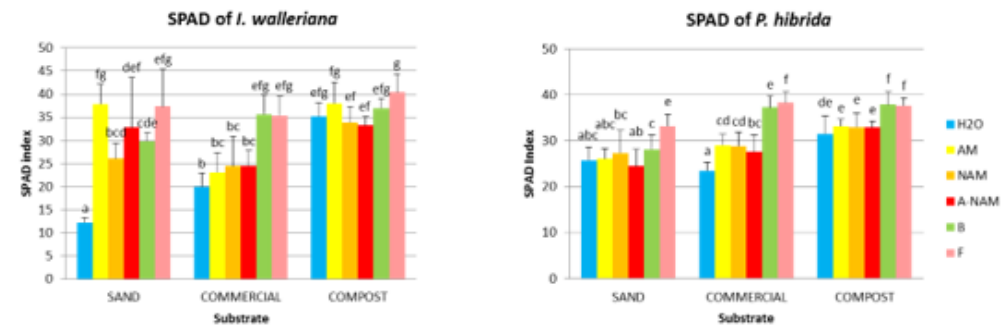

Figure 5

ANOVA of SPAD Index in leaves of Impatiens walleriana and Petunia hibrida growing in different substrates and irrigated with bio-products. H2O: well water (Control); AM: aerated mixture residues compost tea; NAM: non-aerated residues mixture compost tea; A-NAM: mixture 1:1 of AM and NAM; B: bioslurry; and F: commercial fertilizer.DISCUSSION

\section{Supplementary Files}


This is a list of supplementary files associated with this preprint. Click to download.

- Publicdata.xlsx

Page 16/16 